\title{
The Effective Role of Jordanian Public Universities as Productive Institutions from the Academic Leaders Perspective
}

\author{
Dr. Ali Odeh Tarawneh ${ }^{1^{*}} \quad$ Prof. Ahmad Battah ${ }^{2}$ \\ 1.Director of the cognitive Creativity Academy for Training, Jordan \\ 2.Professor of Educational Administration at the University of Jordan
}

\begin{abstract}
The present study aimed to explore the effective role of Jordanian public universities as productive institutions from the perspective of academic leaders. A questionnaire was used and a descriptive approach was adopted. 323 questionnaire forms were distributed to academic leaders. Those leaders were selected from three Jordanian public universities; (the University of Jordan, Yarmouk University, and Mu'tah University). The present study aimed to identify whether there is any statistically significant difference between the respondents' attitudes which can be attributed to (their leadership position, or faculty or the university they graduated from). 287 questionnaire forms were retrieved. The stratified random sampling method was used. It was found that the Jordanian public universities play a very effective role as productive universities from the perspective of the academic leaders. That's because the overall mean is 3.96 . The overall standard deviation is 0.18 . It was found that there isn't any statistically significant difference between the respondents' attitudes.
\end{abstract}

Keywords: productive university, academic leaders

DOI: $10.7176 / \mathrm{JEP} / 10-35-15$

Publication date: December $31^{\text {st }} 2019$

\section{Introduction}

Universities serve as the source of knowledge. That's because they handle community responsibilities, teach students and support researchers in conducting scientific research. Institutions usually seek developing themselves and raise the performance of their employees and managers of high and middle management levels. Most institutions seek becoming productive institutions. That also applies to higher education institutions, including universities.

High education institutions play a significant role in providing the labor market with workforce that possess essential skills.. They also play a significant role in raising the productivity level. To meet such goals, higher education institutions must train individuals and provide them with essential skills. Through analyzing the experiences of the countries which economic systems have developed rapidly, developing the technological capabilities of individuals and increasing the investments made in universities require having an adequate number of engineers and scientists who are specialized in various fields. Achieving that requires making adjustments to the investment climate in higher education institutions (Jaramillo, 2009).

Higher education institutions provide society with qualified workforce - that possess skills and expertise- each year in various fields. Such fields may include: pedagogy, medicine, engineering, economy and Islamic studies. These institutions have many academic programs that participate in developing the members of the society. That shall participate in increasing the number of investments and raising productivity. In short, universities must provide the society with the needed labor force. They must achieve consistency between their academic programs and the labor force needed by society. That must be done in order for universities to become productive.

Many universities -in advanced countries-are considered very productive universities that conduct investments. Such universities may include Harvard University, Stanford University, and Massachusetts Institute of Technology. They have provided many innovations and discovered many things. Such innovations have facilitated the way people carry out tasks. Such universities have participated in the development of the countries they are located at (Battah, 2017).

The term (productive university) is a very important term that must be provided with adequate attention. Universities can become productive through achieving consistency between their goals and the society's needs. They can become so through providing the society with people who possess academic \& scientific expertise in various fields and areas. That shall participate in increasing the number of the investment opportunities. University can become productive through providing attention to scientific research, delivering community service, and launching entrepreneurship projects. They can become productive through achieving consistency between the labor market requirements and the available academic programs. They can become productive through increasing the number of the available job opportunities.

\section{Statement of the Problem:}

The productivity level of Jordanian universities is low. It can be noticed that there is a great number of Jordanians who graduated from universities. There's also a great number of theses that are published by Jordanian universities. 
Such theses are used only as references. In addition, Jordanian universities do not carry out many community activities. Based on many Arab and foreign studies, it's important to conduct studies about the effective role of universities as productive universities. That's emphasized by the studies conducted by Bani Maqdad (2016), Bufaltah (2015), Mantikayan, and Abdulgani (2017). Thus, the present study aimed to explore the effective role of Jordanian public universities as productive universities from the perspective of academic leaders.

\section{The Study's Questions:}

Q.1. How effective the Jordanian public universities are as productive institutions from the perspective of academic leaders?

Q.2. Is there any statistically significant difference -at the statistical significance level of $a \leq 0.05$ - between the respondents' attitudes which can be attributed to (their leadership position, or faculty or the university they graduated from)?

\section{The study's objectives:}

\section{The present study aimed to:}

Identify the effective role of Jordanian public universities as productive universities from the perspective of academic leaders

- Identify whether there is any statistically significant difference -at the statistical significance level of $\mathrm{a} \leq 0.05$ - between the respondents' attitudes which can be attributed to (their leadership position, or faculty or the university they graduated from).

- Propose effective mechanisms for activating the role of Jordanian public universities as productive universities.

\section{The study's significance:}

The present study is significant because it's useful for the following:

Public Jordanian universities: This study is significant because it aimed at activating the role of Jordanian public universities as productive universities

- Academic leaders: This study is significant because it shall encourage academic leaders at Jordanian public universities to activate the role of universities as productive universities

- Decision makers at the Ministry of Higher Education: This study is significant because it provides researchers with a review for the relevant literature. Such review can assist researchers when conducting a similar study.

\section{The Study's Terms:}

- Productive university: It refers to the university that carries out activities in the aim of generating profit. Carrying out such activities shall positively affect the leaders and employees at the productive university. However, such activities must be consistent with the vision of the university (Hamed et al., 2008). The present study aimed to explore the effective role of Jordanian public universities as productive universities in three areas; (education, scientific research, and community responsibility). It aimed to identify that from the perspective of the academic leaders working at Jordanian public universities.

- Jordanian public universities: They refer to higher education institutions that provide one with education after he/she receives school education. These institutions provide attention to (education, scientific research, and community responsibility). They grant people academic degrees, such as: BA, MA and PhD degrees. They are supervised directly by the higher education council (The Jordanian universities act and its amendments, 2018).

- Academic leaders: This term refers to the ones responsible for running higher education institutions including universities. It refers to the ones responsible for running colleges and departments. They do that in accordance with specific conditions and standards. Such conditions and standards are connected to major and academic rank. The sample of this study consists of academic leaders; (deans, vice dean, and head of the department). The members of the sample vary in term of (the leadership position, or faculty or the university they graduated from).

\section{The Study's Limits:}

The present study aimed to explore the effective role of Jordanian public universities as productive institutions from the perspective of academic leaders during the academic year (2018/2019). The sampled leaders include: (deans, vice deans, and heads of the departments).

\section{Theoretical literature}

Researchers have been providing much attention to the educational systems and higher education institutions. 
Today, universities must become productive and conduct investments. That's needed due to the following reasons (Dryden, 2002):

- The world is affected by ICT revolution, more than it is affected by the industrial revolution, or the invention of electricity, or the printer

- Today, each country is in need for having a revolution in the educational field for adapting itself with the ICT revolution

- There must be innovations made in each profession in order for the profession to survive

According to Choy \& Delahaye (2011), it is necessary to establish partnerships between universities and companies. Universities must also design curricula that meet the needs of the labor market. That shall participate in connecting the theoretical knowledge with the practical one (Choy \& Delahaye, 2011).

\section{The Study's Approach:}

A questionnaire was used and a descriptive approach was adopted.

\section{The Study's Population:}

The study's population consists from all the academic leaders who work at Jordanian public universities. The sampled leaders include: (deans, vice deans, and heads of the departments). Based on the statistical data issued by the Ministry of Higher Education, the study's population consists from 809 leaders. The stratified random sampling method was used to select a sample from the population. The population involves academic leaders who were selected from northern, southern and central areas of Jordan. The relevant data is presented in table (1):

Table (1): The distribution of the members of the population in accordance with the leadership position

\begin{tabular}{|c|c|c|c|c|}
\hline \multirow[t]{2}{*}{ University } & \multicolumn{3}{|c|}{ Leadership position } & \multirow[t]{2}{*}{ Total } \\
\hline & Dean & Vice dean & Head of a department & \\
\hline The University of Jordan & 22 & 30 & 89 & 141 \\
\hline The German Jordanian University & 10 & 11 & 16 & 37 \\
\hline The Hashemite University & 17 & 15 & 41 & 73 \\
\hline Al-Albait University & 11 & 12 & 26 & 49 \\
\hline Al-Balqa Applied University & 18 & 27 & 89 & 134 \\
\hline Al-Huassin bin Talal University & The acting dean & 1 & 65 & 66 \\
\hline Al-Tafileh Technical University & 9 & 4 & 18 & 31 \\
\hline Jordan University of Science and Technology & 15 & 23 & 58 & 96 \\
\hline Yarmouk University & 17 & 18 & 65 & 100 \\
\hline Mu'tah University & 12 & 17 & 53 & 82 \\
\hline Total & 131 & 158 & 520 & 809 \\
\hline
\end{tabular}

The study's sample:

The stratified random sampling method was used. 323 questionnaire forms were distributed to academic leaders. Those leaders were selected from three Jordanian public universities; (the University of Jordan, Yarmouk University, and Mu'tah University). They were selected from northern, southern, and central areas of Jordan. 287 questionnaire forms were retrieved. Data about the sample is presented in table (2) below:

Table (2): The distribution of the members of the sample in accordance with several variables

\begin{tabular}{|l|l|l|l|}
\hline Variable & Category & Frequency & Percentage \\
\hline \multirow{4}{*}{ Leadership position } & Dean & 32 & $\% 11$ \\
\cline { 2 - 4 } & Vice dean & 61 & $\% 21$ \\
\cline { 2 - 4 } & Head of a department & 194 & $\% 68$ \\
\hline \multirow{2}{*}{ Faculty } & Scientific faculty & 197 & $\% 69$ \\
\cline { 2 - 4 } & Human science faculty & 90 & $\% 31$ \\
\hline \multirow{2}{*}{$\begin{array}{l}\text { The university } \\
\text { graduated from }\end{array}$} & Arab university & 93 & $\% 32$ \\
\cline { 2 - 4 } & Foreign university & 192 & $\% 67$ \\
\cline { 2 - 4 } & Total & 287 & $\% 100$ \\
\hline
\end{tabular}

\section{The Study's Instrument:}

To meet the study's goals, the researchers developed a questionnaire. This questionnaire aims to explore the effective role of Jordanian public universities as productive universities from the perspective of academic leaders. It consists from 40 items. It covers three areas; education (15 items), scientific research (16 items), and community responsibility (9 items). This questionnaire was developed based on the relevant studies. Such studies include: the studies conducted by Bani Maqdad (2016), Bufaltah (2015), Mantikayan, and Abdulgani (2017). The five point Likert scale was adopted. It consists from the following categories: strongly agree, agree, moderate, disagree and 
strongly disagree.

Validity of the Instrument:

The researchers checked the content validity. For instance, they passed the initial version of the questionnaire to 18 experts to provide their opinion about the questionnaire. That was done to make sure that the questionnaire measures what it aims to measure. Most of the experts recommended re-drafting some items.

Reliability of the Instrument

To measure the reliability of the instrument, Cronbach Alpha coefficient values were calculated. These values are presented in table 3 in accordance with the targeted area. In addition, the test-re-test method was used to measure the reliability of the instrument.

Table (3): The values of the Cronbach Alpha coefficient and the test-re-test coefficient of each area

\begin{tabular}{|l|l|l|}
\hline Area & Test-re-test coefficient & Cronbach Alpha coefficient \\
\hline Sig. & $* * 0.683$ & 0.97 \\
\hline Education & $* * 0.676$ & 0.92 \\
\hline Scientific research & $* * 0.652$ & 0.95 \\
\hline Community responsibility & 0.147 & 0.84 \\
\hline
\end{tabular}

$(*)$ : This sign means that the value is statistically significant

Table (3) indicates that the values of the test-re-test coefficient are statistically significant in the areas of education and scientific research. However, the value of the test-re-test coefficient isn't statistically significant in the community responsibility area (0.147). It was found that the values of the Cronbach Alpha coefficient are high because they are greater than 0.60 .

Results related to the first question

Q.1. How effective the Jordanian public universities are as productive institutions from the perspective of academic leaders?

To answer this question, means and standard deviations were calculated. These values are displayed through tables $(4,5,6$ and 7$)$.

Table (4): Means and standard deviations for identifying the effective role of Jordanian public universities as productive institutions from the perspective of academic leaders

\begin{tabular}{|c|l|l|l|l|l|}
\hline Rank & Area & Items & Mean & Std. & level \\
\hline 1. & Scientific research & $16-31$ & 4.02 & 0.20 & High \\
\hline 2. & Community responsibility & $32-40$ & 3.95 & 0.20 & High \\
\hline 3. & Education & $15-1$ & 3.90 & 0.27 & High \\
\hline & Total & $40-1$ & 3.96 & 0.18 & High \\
\hline
\end{tabular}

Based on table (4), it can be noticed that Jordanian public universities play a very effective role as productive institutions, because the overall mean is 3.96. The overall standard deviation is 0.18 . It was found that the scientific research area is ranked first, because its mean is 4.02 . Its standard deviation is 0.20 . The community responsibility area is ranked second, because its mean is 3.95. Its standard deviation is 0.20 . The educational area is ranked third, because its mean is 3.90. Its standard deviation is 0.27 . All the means are high. That means that Jordanian public universities provide much attention to education, community responsibility and scientific research. However, the productivity of Jordanian public universities isn't as it is ought to be. It can be noticed that the number of the ones enrolling in Jordanian public universities has been increasing. That led to raising the unemployment rates among the individuals whose major isn't needed much in the labor market. It can be noticed that numerous theses are published by students and numerous studies are published in journals by faculty members in Jordanian public universities. Such studies and theses are used only for getting a promotion and obtaining a higher academic rank. Such studies and theses don't play an effective role in developing society. In addition, it can be noticed that there isn't enough cooperation between Jordanian public universities and other institutions. However, having such cooperation is required for handling community responsibilities. It should be noted that universities aren't a place for providing people with education only. In fact, they are responsible for achieving development in society. 
The results below are presented in accordance with each area:

The educational area:

Table 5: The role of Jordanian public universities as productive institution in the educational area:

\begin{tabular}{|c|c|c|c|c|c|}
\hline Rank & $\begin{array}{l}\text { Statement } \\
\text { No. }\end{array}$ & Statement & Mean & Std. & Level \\
\hline 1 & 4 & $\begin{array}{l}\text { The university provides (e-learning and distance learning) } \\
\text { services }\end{array}$ & 4.14 & 0.51 & High \\
\hline 2 & 2 & $\begin{array}{l}\text { The university provides (ongoing learning and technical } \\
\text { learning) programs }\end{array}$ & 4.02 & 0.54 & High \\
\hline 3 & 3 & $\begin{array}{l}\text { The university has a learning environment that participates in } \\
\text { attracting foreign students }\end{array}$ & 4.01 & 0.50 & High \\
\hline 4 & 14 & $\begin{array}{l}\text { The university has a high capacity in terms of student } \\
\text { admission. Such capacity meets the total quality standards }\end{array}$ & 4.00 & 0.45 & High \\
\hline 5 & 8 & $\begin{array}{l}\text { The university advertises its academic programs through using } \\
\text { media }\end{array}$ & 3.98 & 0.76 & High \\
\hline 6 & 5 & $\begin{array}{l}\text { The university keeps up with the latest developments in a } \\
\text { manner that meets the total quality standards in the } \\
\text { educational process }\end{array}$ & 3.97 & 0.60 & High \\
\hline 7 & 12 & $\begin{array}{l}\text { The university provides students with scholarships that are } \\
\text { granted by various bodies }\end{array}$ & 3.93 & 0.64 & High \\
\hline 8 & 9 & The university offers students facilities in order to enroll in it & 3.92 & 0.55 & High \\
\hline 9 & 10 & $\begin{array}{l}\text { The university provides academic programs that are consistent } \\
\text { with the needs of the labor market }\end{array}$ & 3.89 & 0.46 & High \\
\hline 10 & 6 & $\begin{array}{l}\text { The university meets the requirements of the cultural } \\
\text { exchange programs which are carried out in collaboration with } \\
\text { local and foreign universities. }\end{array}$ & 3.86 & 0.56 & High \\
\hline 11 & 1 & $\begin{array}{l}\text { The university has an appropriate environment that attracts } \\
\text { faculty members who possess much expertise and excellent } \\
\text { academic qualifications }\end{array}$ & 3.83 & 0.58 & High \\
\hline 12 & 7 & $\begin{array}{l}\text { The university provides students with training programs in } \\
\text { technical and scientific majors }\end{array}$ & 3.80 & 0.64 & High \\
\hline 13 & 11 & $\begin{array}{l}\text { The university provides the latest means and technologies to } \\
\text { ensure that the teaching process shall be carried effectively }\end{array}$ & 3.74 & 0.75 & High \\
\hline 14 & 13 & $\begin{array}{l}\text { The university collaborates with private institutions through } \\
\text { (establishing faculties, and lecture halls, and improving the } \\
\text { quality of the infrastructure services) }\end{array}$ & 3.69 & 0.72 & High \\
\hline \multirow[t]{2}{*}{15} & 15 & $\begin{array}{l}\text { The university complies with the transparency and fairness } \\
\text { principles in terms of student admission }\end{array}$ & 3.66 & 0.74 & Moderate \\
\hline & & Total & 3.90 & 0.27 & Moderate \\
\hline
\end{tabular}

Based on table (5), it was found that Jordanian public universities play a very effective role as productive institutions in the educational area. That's concluded from the perspective of academic leaders. That's because the overall mean is 3.90. The overall standard deviation is 0.27 . Statement 4 is ranked first because its mean is high (4.14) and its standard deviation is 0.51 . It states the following: (The university provides (e-learning and distance learning) services). Statement 15 is ranked last because its mean is 3.66 which is moderate. The standard deviation of statement 15 is 0.74 . It states the following (The university complies with the transparency and fairness principles in terms of student admission). 
Scientific research:

Table 6: The role of Jordanian public universities as productive university in the scientific research area:

\begin{tabular}{|c|c|c|c|c|c|}
\hline Rank & $\begin{array}{l}\text { Statement } \\
\text { No. }\end{array}$ & Statement & Mean & Std. & Level \\
\hline 1 & 27 & $\begin{array}{l}\text { The university provides adequate funds for supporting } \\
\text { scientific research }\end{array}$ & 4.45 & 0.67 & High \\
\hline 2 & 19 & $\begin{array}{l}\text { The university encourages people to conduct innovative } \\
\text { research works }\end{array}$ & 4.39 & 0.64 & High \\
\hline 3 & 22 & $\begin{array}{l}\text { The university established a network for advertising scientific } \\
\text { research }\end{array}$ & 4.25 & 0.74 & High \\
\hline 4 & 18 & $\begin{array}{l}\text { The university allows students to utilize the outcomes of } \\
\text { scientific research }\end{array}$ & 4.10 & 0.45 & High \\
\hline 5 & 31 & $\begin{array}{l}\text { The university has its own journal that publishes peer- } \\
\text { reviewed studies }\end{array}$ & 4.10 & 0.51 & High \\
\hline 6 & 25 & The university adopts a rational research policy. & 4.05 & 0.72 & High \\
\hline 7 & 24 & $\begin{array}{l}\text { The university engages with other universities in programs that } \\
\text { require adopting common criteria that govern the kind of } \\
\text { journals that faculty members can publish their studies at. That } \\
\text { is done for reducing the publication costs }\end{array}$ & 4.01 & 0.61 & High \\
\hline 8 & 20 & The university protects the intellectual property rights & 4.01 & 0.57 & High \\
\hline 9 & 21 & $\begin{array}{l}\text { The university provides the faculty members with facilities for } \\
\text { conducting research, such as: sabbatical leaves }\end{array}$ & 3.98 & 0.44 & High \\
\hline 9 & 26 & $\begin{array}{l}\text { The university assesses the scientific research based on the } \\
\text { total quality standards }\end{array}$ & 3.98 & 0.70 & High \\
\hline 11 & 28 & $\begin{array}{l}\text { The university identifies the priorities of scientific research } \\
\text { based on the needs of society. }\end{array}$ & 3.97 & 0.52 & High \\
\hline 12 & 30 & $\begin{array}{l}\text { The university encourages individuals to carry out group- } \\
\text { based research works in order to participate in addressing } \\
\text { several issues }\end{array}$ & 3.90 & 0.52 & High \\
\hline 13 & 16 & $\begin{array}{l}\text { The university utilizes the available resources to activate the } \\
\text { role of scientific research }\end{array}$ & 3.88 & 0.49 & High \\
\hline 14 & 29 & $\begin{array}{l}\text { The university plays a significant role in developing } \\
\text { researchers and their assistants }\end{array}$ & 3.88 & 0.54 & High \\
\hline 15 & 23 & $\begin{array}{l}\text { The university achieves a balance between the outcomes of } \\
\text { scientific research in various disciplines }\end{array}$ & 3.82 & 0.79 & High \\
\hline \multirow[t]{2}{*}{16} & 17 & $\begin{array}{l}\text { The university provides researchers with easy access to } \\
\text { research databases }\end{array}$ & 3.64 & 0.70 & Moderate \\
\hline & & Total & 4.02 & 0.20 & High \\
\hline
\end{tabular}

Based on table (6), it was found that Jordanian public universities play a very effective role as productive institutions in the scientific research area. That was concluded from the perspective of academic leaders. That's because the overall mean is 4.02. The overall standard deviation is 0.20 . Statement 27 is ranked first, because its mean is 4.45 . This mean is high. The standard deviation of this statement is 0.67 . The latter statement states the following: (The university provides adequate funds for supporting scientific research). This result may be attributed to the fact that universities provide much attention to increasing the funds dedicated for supporting the scientific research. That can be manifested through establishing the Scientific Research Support Fund. However, the Jordanian universities do not provide much attention to how effective the role of the scientific research outcomes are. In addition, the funds dedicated for supporting researchers are not adequate as they ought to be. There isn't any efficient plan that regulate the process of funding the scientific research that aims at addressing major issues in society. Statement (17) states the following: (The university provides researchers with easy access to research databases). The mean of this statement is 3.64 which is moderate and ranked last. The standard deviation of this statement is 0.70 . That may be attributed to the fact that the sampled universities do not provide researchers with access to an adequate number of databases. That shall negatively affect the advertisement of the studies published by the faculty members and students of the university. 
Community responsibility:

Table 7: The role of Jordanian public universities as productive institutions in the social responsibility area:

\begin{tabular}{|l|l|l|l|l|l|}
\hline Rank & $\begin{array}{l}\text { Statement } \\
\text { No. }\end{array}$ & Statement & Mean & Std. & Level \\
\hline 1 & 39 & $\begin{array}{l}\text { The university seeks providing scientific research that is oriented } \\
\text { to handling the community responsibility }\end{array}$ & 4.39 & 0.52 & High \\
\hline 2 & 37 & $\begin{array}{l}\text { The university provides opportunities for conducting investments } \\
\text { in the private and public sectors }\end{array}$ & 4.04 & 0.51 & High \\
\hline 3 & 40 & $\begin{array}{l}\text { The university seeks developing databases in terms of the } \\
\text { (society's needs, and the demands of the labor market) That } \\
\text { participates in increasing the number of the available investment } \\
\text { opportunities in society }\end{array}$ & 4.02 & 0.64 & High \\
\hline 4 & 35 & $\begin{array}{l}\text { The university develops programs for supporting creative people. } \\
\text { That participates in increasing the number of the available } \\
\text { investment opportunities in society }\end{array}$ & 3.96 & 0.61 & High \\
\hline 5 & 34 & $\begin{array}{l}\text { The university seeks maximizing the productivity level. That } \\
\text { facilitates the process of extracting natural resources. }\end{array}$ & 3.94 & 0.20 & High \\
\hline 7 & 33 & $\begin{array}{l}\text { The university seeks encouraging its students to handle } \\
\text { community responsibilities }\end{array}$ & 3.86 & 0.50 & High \\
\hline 9 & 38 & $\begin{array}{l}\text { The university seeks achieving social stability in the aim of } \\
\text { developing the society in various areas. }\end{array}$ & 3.84 & 0.66 & High \\
\hline & $\begin{array}{l}\text { The university seeks ensuring that its employees have decent } \\
\text { living conditions. That shall participate in increasing the } \\
\text { investment and productivity levels of the society }\end{array}$ & $\begin{array}{l}\text { The university seeks providing the labor market with qualified } \\
\text { individuals }\end{array}$ & 3.75 & 0.55 & High \\
\hline Total & 763 High \\
\hline
\end{tabular}

Based on table 7, it was found that the Jordanian public universities play a very effective role as productive institutions in the community responsibility area. That was concluded from the perspective of academic leaders. That's because the overall mean is 3.95. The overall standard deviation is 0.20 . Statement 39 is ranked first, because its mean is 4.39. This mean is high. The standard deviation of this statement is 0.52 . The latter statement states the following: (The university seeks providing scientific research that is oriented to community responsibility). This result may be attributed to the fact that the sampled universities seek providing scientific research that meets the needs of the society. It should be noted that Jordanian public universities provide numerous studies that seek meeting the needs of the civil society institutions. However, such studies do not meet the requirements of achieving sustainable development. Statement (38) states the following: (The university seeks providing the labor market with qualified individuals). The mean of this statement is 3.75 which is ranked last. It's considered a high mean. The standard deviation of this statement is considered 0.63 . This result may be attributed to the fact that Jordanian public universities seek developing their students through providing them with the required courses. Such provision shall participate in providing the labor market with qualified labor force. However, the researchers of the present study believe that there must be training and research centers for meeting the needs of all the sectors in society, including the political, social, economic and educational sectors. Having such centers shall provide the labor market with qualified labor force.

The second question: Is there any statistically significant difference -at the statistical significance level of $\mathrm{a}=0.05$ - between the respondents' attitudes which can be attributed to (the leadership position, faculty or the university they graduated from)?

To identify whether there is any statistically significant difference between the respondents' attitudes which can be attributed to the leadership position, the researchers conducted one-way analysis of variance (ANOVA). To identify whether there is any statistically significant difference between the respondents' attitudes which can be attributed to faculty or the university they graduated from, the researchers conducted the t-test. The results in this regard are presented through tables $(8,9$ and 10$)$. 
The detailed answer of question 2 is presented below in accordance with each variable

The leadership position.

Table (8): The results of the one-way analysis of variance (ANOVA) for identifying the respondents' attitudes in accordance with the leadership position

\begin{tabular}{|l|l|l|l|l|}
\hline Area & Sum of squares & F value & Degree of freedom & Sig. \\
\hline Education & 0.024 & 0.98 & 286 & 0.584 \\
\hline Scientific research & 3.724 & 0.49 & 286 & 0.575 \\
\hline Social responsibility & 0.498 & 0.67 & 286 & 0.620 \\
\hline Total & 0.827 & 0.39 & 286 & 0.436 \\
\hline
\end{tabular}

Based on table (8), it was found that there isn't any statistically significant difference between the respondents' attitudes which can be attributed to the leadership position. That indicates that the respondents in various leadership positions have similar views about the effective role of Jordanian public universities as productive universities. This result is attributed to the fact that the work environments of Jordanian public universities are similar. The researchers believe that decision makers must propose mechanisms for activating the role of Jordanian public universities as productive universities.

The faculty variable:

Table (9): The results of the t-test for identifying the respondents' attitudes in accordance with faculty

\begin{tabular}{|c|c|c|c|c|c|c|}
\hline Area & Faculty & Mean & Std. & $\mathrm{T}$ value & Degree of freedom & Sig. \\
\hline \multirow[t]{2}{*}{ Education } & Scientific faculty & 2.73 & 0.63 & \multirow{2}{*}{.580} & \multirow{2}{*}{286} & \multirow{2}{*}{8.542} \\
\hline & Human faculty & 2.77 & 0.61 & & & \\
\hline \multirow[t]{2}{*}{ Scientific research } & Scientific faculty & 2.77 & 0.70 & \multirow{2}{*}{.790} & \multirow{2}{*}{286} & \multirow{2}{*}{7.966} \\
\hline & Human faculty & 2.82 & 0.71 & & & \\
\hline \multirow{2}{*}{$\begin{array}{l}\text { Social } \\
\text { responsibility }\end{array}$} & Scientific faculty & 2.70 & 0.70 & \multirow{2}{*}{.680} & \multirow{2}{*}{286} & \multirow{2}{*}{2.849} \\
\hline & Human faculty & 2.66 & 0.70 & & & \\
\hline \multirow[t]{2}{*}{ Total } & Scientific faculty & 2.74 & 0.61 & \multirow{2}{*}{.680} & \multirow{2}{*}{286} & \multirow{2}{*}{0.217} \\
\hline & Human faculty & 2.74 & 0.61 & & & \\
\hline
\end{tabular}

Based on table (9), it was found that there isn't any statistically significant difference between the respondents' attitudes which can be attributed to the faculty. That may be attributed to the fact that Jordanian public universities seek complying with the (productive university) principles. That's because complying with such principles shall participate in increasing the funding and investment opportunities.

Table (10): The results of the t-test for identifying the respondents' attitudes in accordance with the university they graduated from

\begin{tabular}{|c|c|c|c|c|c|c|}
\hline Area & University & Mean & Std. & $\mathrm{T}$ value & Degree of freedom & Sig. \\
\hline \multirow[t]{2}{*}{ Education } & Arab University & 2.76 & 0.58 & \multirow{2}{*}{0.79} & \multirow{2}{*}{286} & \multirow{2}{*}{0.106} \\
\hline & Foreign University & 2.75 & 0.63 & & & \\
\hline \multirow[t]{2}{*}{ Scientific research } & Arab University & 2.74 & 0.58 & \multirow{2}{*}{0.64} & \multirow{2}{*}{286} & \multirow{2}{*}{0.765} \\
\hline & Foreign University & 2.82 & 0.73 & & & \\
\hline \multirow[t]{2}{*}{ Social responsibility } & Arab University & 2.63 & 0.70 & \multirow{2}{*}{0.95} & \multirow{2}{*}{286} & \multirow{2}{*}{0.526} \\
\hline & Foreign University & 2.69 & 0.69 & & & \\
\hline \multirow[t]{2}{*}{ Total } & Arab University & 2.71 & 0.55 & \multirow{2}{*}{0.26} & \multirow{2}{*}{286} & \multirow{2}{*}{0.455} \\
\hline & Foreign University & 2.80 & 0.64 & & & \\
\hline
\end{tabular}

Based on table (10), it was found that there isn't any statistically significant difference between the respondents' attitudes which can be attributed to the university they graduated from. That may be attributed to the fact that the Jordanian public universities have similar administrative policies that regulate the process of becoming productive institutions. This result indicates that the university that the respondent has graduated from doesn't affect his/her attitudes in this regard.

The term (productive university):

The outcomes of higher education institutions -including universities- are considered the basis for achieving sustainable development in society. Therefore, the term (productive university) is connected to development. For instance, universities are responsible for providing the society with individuals who possess academic and scientific expertise in various fields. They are responsible for providing the society with individuals who participate in the development of society. There is a debate among researchers about the term (productive university).

According to Bufaltah (2015), the productive university refers to the university that carries out activities that generate funds for itself. The generation of funds shall positively affect the university itself and its employees. According to Bani Maqdad (2016), the productive university refers to the university that provides the society with services in the field of education, and scientific research. The productive university seeks funding itself through 
investing its financial and human resources optimally. It seeks establishing partnerships with the civil society institutions in order to ensure survival.

The effective productive university carries out several functions in the fields of (education, scientific research, and community responsibility). Institutions can invest in such a university. That shall participate in funding the productive university. It shall participate in providing the society and public bodies with qualified labor force in various disciplines

The functions of the productive university:

Universities play a significant role in providing the society with people who possess expertise in various academic and research fields. Such provision shall participate in raising the welfare level of the members of the society. It shall participate in the development of the society in various fields. The most important functions of the productive university include:

First: Education:

Providing people with education is the main function performed by university. For instance, each year, numerous students are enrolled in universities. That's because people want to receive education in the aim of meeting the demands of the labor market.

According to Azb (2011), university education enables the nation to develop in technological and scientific areas. It also enables the nation to advance in a manner that's consistent with the needs of society. It provides society with qualified human resources in various areas and domains.

Choy \& Delahaye (2011) suggest that it's important to activate the role of the partnerships existing between universities and business institutions. That must be done through designing academic programs and curricula that meet the demands of the labor market. That shall participate in achieving a connection between the theoretical knowledge and the practical one.

\section{The goals sought from providing university education:}

According to UNESCO (2008), higher education is provided in the aim of:

1- Promoting awareness among citizens about various issues. Higher education is provided in the aim of promoting compliance with social and national principles among citizens. It's provided in the aim of enabling citizens to handle the contemporary challenges. It's provided in the aim of encourage citizens to practice on-going learning.

2- Developing qualified human resources who are capable of meeting the demands of the private, public, service and production sectors. Higher education is provided in the aim of having people who are selfemployed

3- Achieving development in technological, social and economic areas and areas related to scientific research. That can be done through providing the society with people who have much expertise.

4- Promoting and protecting the national culture.

5- Encouraging people to provide objective criticism against the strategies that aim at boosting development. Higher education is provided in the aim of generating scientific knowledge, along with showing compliance with the code of ethics. It's provided in the aim of handling global challenges, such as: the environmental challenges and the challenges related to peace and the increasing population.

6- Exploring the most important problems that the region is suffering from. Higher education is provided in the aim of providing solutions for such problems. That can be done through conducting studies and providing discretionary opinions.

Kamal Al-Deen (2009) suggests that higher education is provided in the aim of:

1- Providing the society with alumni who are highly qualified. Higher education is provided in the aim of developing citizens and enabling them to meet the demands of various sectors

2- Encouraging people to practice on-going learning

3- Promoting knowledge through using creative methods. Higher education is provided in the aim of developing knowledge through conducting studies. It's provided in the aim of providing the society with people who possess much expertise. That shall participate in achieving development in social, economic and cultural areas.

4- Promoting and interpreting global and national cultures and cultures of ancient civilizations. Higher education is provided in the aim of promoting acceptance for multiculturalism in society.

5- Instilling community values within people, especially among young people. Higher education is provided in the aim of promoting democratic citizenship

6- Improving the quality of education. That can be achieved through developing teachers professionally.

\section{The significance of university education}

Namour (2012) adds that university education is very important due to its role in the investment areas. For instance, university education participates in: 
1- Increasing one's production capacity and capabilities to generate income.

2- Increasing the society's production capacity. That shall participate in increasing the national income and the overall social and financial welfare levels.

3- Identifying people's orientations and interests. University education participates in exploiting such interests for the favor of the society and the national economy.

4- Improving one's capabilities in conducting scientific research, in the aim of solving the society's problems and achieving economic growth

5- Improving one's capacity to adjust himself/ herself with the labor market demands in any sector (Namour, 2012)

Al-Tarawneh (2015) adds that university education is very important from the following perspectives:

1- Economic perspective: Higher education participates in developing qualified and well-trained human resources

2- Social perspective: Higher education participates in improving one's cognitive, and intellectual capabilities. It also participates in instilling positive values within one. It encourages one to show good behaviors

3- Security perspective: Higher education participates in reducing the unemployment rates. That shall participate in promoting security in society

4- Educational perspective: Higher education participates in providing society with people who are capable of innovating, researching, and developing things. That shall participate in improving the living conditions of citizens. It shall enable the society to advance in various areas.

Higher education institutions are very important due to the following reasons:

1- Higher education institutions provide the society with experts in political, social, educational, economic, technological, medical, engineering, and etc.. fields.

2- Higher education institutions enable one to improve the quality of his/her own life. They enable societies to improve the quality of their citizens' lives. In other words, receiving higher education enable people to live a luxurious life and have a respected social rank and financial status.

3- Higher education institutions enable individuals and societies to enjoy intellectual maturity. That shall improve the competitiveness of countries in the global market.

4- Higher education institutions enable countries to solve their problems and handle challenges through using advanced scientific methods

\section{Second: scientific research}

Universities must conduct scientific research in order to handle the challenges faced by the society. Conducting scientific research shall enable universities to identify the strengths of society in order to boost them. It shall enable universities to identify the weaknesses of society in order to address them. Several social, economic, scientific and technological changes have occurred in the international arena, especially in the Arab arena. Therefore, major changes must be made to the mission, functions, roles and duties of universities. That must be done to handle challenges, meet the society's needs and keep up with the latest developments (Al-Khateeb, 2009).

Today, the assessment of the validity and reliability of knowledge isn't based on personal experience nor hunch. In fact, reliable and valid knowledge can be obtained today through conducting scientific research. Due to experiencing knowledge explosion, the World Wide Web has become the source of knowledge instead of books, and microfilms. Thus, the web today serves as a source of knowledge (Ibrahim, 2014). Countries today compete with one another in terms of the scientific research. Such competition occurs, because each country wants to meets its goals. Through conducting scientific research, researchers can come up with new theories, creative works and inventions and propose new visions. Therefore, through conducting scientific research, the country shall be able to develop and advance in the economic, social, political, or cultural field or in all these fields jointly (Battah, 2017).

\section{The meaning of the term (scientific research)}

Before identifying the meaning of scientific research, the meaning of the term (science) must be identified. The term (science) refers to a set of theories, information and facts in a specific field (Ya'qoub, 2011). The term (scientific approach) refers to an approach that is adopted in the aim of conducting research, and finding scientific facts. It also refers to the method used by the researcher for conducting his research (E'naya, 2014). The term (scientific research) refers to an organized investigation of something or several things. This investigation is conducted in the aim of increasing, applying or adjusting knowledge (Ibrahim, 2014). In the light of the aforementioned, scientific research refers to an investigation conducted in the aim of solving problems, providing answers to questions, and providing reliable knowledge about something. It's conducted through reviewing several references. There are various fields of scientific research. There are centers that are specialized in scientific research. 
Conditions for conducting scientific research:

When analyzing several definitions for the term (scientific research), it can be noticed that there are several conditions that must be met by the researcher. Such conditions include the following:

1- The researcher must be acquainted with the study's problem.

2- The researcher must develop hypotheses and set questions that address the study's problem. The results of the study must include answers for the study's questions.

3- The researcher must adopt a scientific methodology for testing the study's hypotheses or answering the study's questions

4- The researcher must draft the study's results in a scientific and clear manner. The results must be reached based on the previous literature and studies

5- The results must be generalized to the sample of the study in accordance with the study's limits (Battah, 2017).

\section{Supporting the scientific research in Jordan:}

Scientific research serves as an indicator for the quality of the outcomes of the higher education institutions. The amount of expenditure spent on the higher education institutions in Jordan has increased. As for the amount of the expenditure spent on scientific research in Jordan, it didn't increase. In facts, it has decreased by $1 \%$. However, the amount of the hi expenditure spent on scientific research in Japan increased by $3.4 \%$, in Germany by $2.85 \%$ and in France by 2.2\%). The Jordanian government established a Scientific Research Support Fund. The latter fund provides support to public Jordanian universities in the aim of turning the national economy into a knowledgebased economy. This support is provided to increase the national productivity in all the areas and activate the role of scientific research in improving economy.

Table (11) presents the budget of the Scientific Research Support Fund in comparison to the expenditures of the Jordanian universities during the period (2016-2016) (cited from the Website of the Economic and Social Council, 2018). Based on the figures presented in the latter table, it can be noticed that the expenditure of the Scientific Research Support Fund is 5.6 million JDs in 2015. The expenditure of the Scientific Research Support Fund is 4.1 million JDs in 2016. Thus, it decreased. It can be noticed that sixty five(65) scholarships were provided in 2016. 16 scientific conferences were supported in 2016. The expenditure dedicated for scientific research by public universities in 2013 is 24.1 million JDs. The expenditure dedicated for scientific research by public universities in 2016 is 30.5 million JDs.

Table (11): The budget of the Scientific Research Support Fund in comparison to the expenditures of the Jordanian universities during the period (2016-2016)

\begin{tabular}{|l|l|l|l|l|}
\hline Item/ Year & 2016 & 2015 & 2014 & 2013 \\
\hline The expenditure of the Scientific Research Support Fund (Million JDs) & 4.1 & 5.6 & 4.6 & 2.7 \\
\hline Scientific research & 3.5 & 4.8 & 4.0 & 2.2 \\
\hline The project of (The management of scientific research program) & 0.06 & 0.07 & 0.07 & 0.01 \\
\hline National research projects & 2.29 & 3.64 & 3.07 & 1.37 \\
\hline Scholarships given to graduate students & 0.60 & 0.63 & 0.42 & 0.34 \\
\hline Faculty member for each factory) program & 0.00 & 0.03 & 0.12 & 0.11 \\
\hline Supporting scientific conferences & 0.19 & 0.11 & 0.09 & 0.12 \\
\hline The support provided for peer-reviewed journals & 0.34 & 0.38 & 0.24 & 0.23 \\
\hline The reward of (scientific research, researcher and peer-reviewers) & 0.00 & 0.00 & 0.00 & 0.01 \\
\hline Post-doctoral scholarships & 0.00 & 0.00 & 0.00 & 0.03 \\
\hline Management and supportive services & 0.7 & 0.8 & 0.6 & 0.4 \\
\hline Total percentage of students (JD) & 13.8 & 19.3 & 15.5 & 9.9 \\
\hline $\begin{array}{l}\text { The number of the scholarships provided/per year for the graduate students who } \\
\text { show excellent academic performance in Jordanian universities }\end{array}$ & 65.0 & 70.0 & 60.0 & 49.0 \\
\hline $\begin{array}{l}\text { The number of the scientific and peer-reviewed conferences that are supervised } \\
\text { by the Jordanian scientific research institutions }\end{array}$ & 16.0 & 13.0 & 14.0 & 17.0 \\
\hline $\begin{array}{l}\text { The number of female researchers who received support for doing their } \\
\text { scientific projects }\end{array}$ & 21.0 & 13.0 & 6.0 & 5.0 \\
\hline $\begin{array}{l}\text { The number of researchers who received support from the fund for doing their } \\
\text { scientific projects }\end{array}$ & 60.0 & 46.0 & 36.0 & 20.0 \\
\hline The expenditure dedicated for scientific research by public universities & 30.5 & 30.5 & 28.5 & 24.1 \\
\hline The expenditure dedicated for scientific research by private universities & 14.0 & 14.4 & 12.3 & 8.9 \\
\hline
\end{tabular}

Source: Statistics issued by the Scientific Research Support Fund (2016). 


\section{Third: The social responsibility:}

Universities play a significant role in societies. For instance, they seek achieving specific goals in political, economic, and social areas. They seek performing functions related to education, scientific research, and community responsibility. They also seek meeting the requirements of achieving sustainable development in society. Therefore, they seek establishing partnerships with civil society institutions. The community responsibilities that must be handled by universities have been addressed by many researchers globally. Such responsibilities must be addressed through university curricula and strategies. That must be done to promote a strategic way of thinking among people (Shaheen, 2012).

\section{The meaning of the term (social responsibility):}

Several definitions are provided for the term (social responsibility). For instance, social responsibility refers to a set of actions and decisions that are made by the organization to meet specific goals and promote specific values among people in society. Meeting such goals shall enable the management of the organization to gain financial benefits (Al-Rahahleh, 2011). Community responsibility refers to the compliance of the university with specific values and principles in order to improve the overall quality of life in society. It involves carrying out functions related to education, research, social interaction and etc.. by the university (Kamal, 2011). It refers to all the activities that are performed by the higher education institutions in order to serve society. It involves functions related to research, education, and etc.. (Ahmadi, 2012). It refers to the capacity to promote values and principles among people and comply with them through carrying out activities related to education, and researching and communicating with the members of the society. It aims at achieving sustainable development in economic, social and environmental areas (Navarrete, 2012). In short, community responsibility is a social and administrative approach that is adopted by academic leaders. It's serves as a basic element of university strategies.

The goals sought from handling community responsibility by universities:

Universities seek handling community responsibility in the aim of (Badat, 2009):

Engaging in intellectual and cultural activities

Conducting scientific studies that provide creative ideas in various areas

Meeting the requirements of achieving sustainable development and handling various challenges.

Addressing several ethical issues and promoting democratic citizenship

Providing students with knowledge, skills and expertise that are needed for meeting the demands of the labor market. Meeting such demands is required in the light of experiencing several rapid changes (Badat, 2009).

In short, universities seek handling social responsibility in the aim of achieving sustainable development. That shall enable universities to fight against poverty, achieve social justice, and meet the needs of the society's members through utilizing the available resources. Through handling social responsibility, universities shall become productive universities.

\section{The dimensions of social responsibility:}

The community responsibility has several dimensions, which are (Shahin, 2012; and Shaqwarah, 2013):

1- The economic dimension: It refers to the compliance of the organization with ethics. It involves carrying out governance-related activities, fighting against bribes \&corruption, protecting the consumers' rights and conducting ethical investments. It involves complying with the principles related to transparency, and accountability and showing ethical behaviors. Handling the community responsibility by universities in economic areas involve:

- Introducing new academic programs in universities that meet the demands of the society. Such programs must enable the society to keep up with the latest scientific developments

- Achieving sustainable development through all the university's activities.

2- The social dimension: Universities must participate in improving the welfare of the society's members. They must seek improving the living conditions of the society's members. That shall positively affect the overall productivity level of the society. They shall improve the capabilities of the society's members and provide them with security. They shall provide the society's members with job security and health care services. Handling the community responsibility by universities in social areas involve:

- Showing respect to the various cultures in existing society and the applicable laws. Handling the community responsibility by universities in social areas involve promoting ethics

Promoting knowledge about the projects that aim at achieving sustainable development

3- The environmental dimension: Universities must provide attention to environment-related issues when carrying out activities, or providing services and products. Handling the community responsibility by universities in environmental areas involve:

- Holding lectures about the significance of protecting the environment from pollution. 


\section{Conducting field studies about the reasons of environmental pollution}

In the light of the aforementioned, universities can handle the community responsibility through ensuring that the provided education shall meet the developmental, professional, cultural, and educational needs of the society's members. They can handle the community responsibility through ensuring that the provided education shall address issues in society.

\section{Obstacles hindering universities from handling the social responsibility:}

There are several obstacles that may hinder universities from handling the social responsibility. Such obstacles include: (Minea, 2013; Moor, 2010; Shaqwarah, 2013):

1- Organizational obstacles: Such obstacles include: poor management, ineffective planning and organization, and refrainment from documenting achievements. Such obstacles include having an organizational structure that leads to having poor communication, and shortage of the information needed for handling the social responsibility.

2- Human-related obstacles: Such obstacles include: shortage of the required human resources, providing university students with inadequate training about the way of handling the community responsibility. Such obstacles include the poor awareness of the faculty members about the role of universities in handling the social responsibility. Such obstacles include the poor awareness of the faculty members about the significance of sharing expertise between the academic institutions and civil society institutions. Such obstacles include the belief that the universities' functions are limited to traditional functions only.

3- Financial obstacles: Such obstacles include: the shortage of the resources needed by universities for handling the social responsibility. Such obstacles include having poor infrastructure.

\section{The principles regulating the process of handling social responsibility: by universities:}

Al-Kuabisy (2011) adds that there are several principles that regulate the process of handling social responsibility by universities, such as:

1- Strengthening the partnerships between universities and civil society institutions. That should be done to increase the number of the available economic opportunities, empower individuals and meet the vision of the higher education institutions

2- Developing a framework for rewarding the (employees, faculty members, students and partners) who commit good behaviors for serving community

3- Promoting awareness among the ones in public bodies, business, media and international organizations about their role in achieving social advancement

4- Establishing partnerships with primary and secondary schools and other higher education institutions.

\section{Models of productive universities:}

Several Arab and foreign universities serve as models of productive universities. Such models are presented below:

\section{1) The US model:}

US universities have been always providing attention to scientific research and technological developments. That's because such attention plays a significant role in achieving economic growth and developing social, business and industrial institutions. It's because such attention plays a significant role in improving the competitiveness of institutions. Therefore, several US universities have established research centers (Boardman, 2009). US productive universities include Harvard University. For instance, the latter university became capable to generate profits through several methods, such as:

1- Denotations: Some donators donate money to Harvard University in order to fund the programs or research projects of Harvard University. Some donators donate money to Harvard University in order to fund the salaries of the faculty members of a specific rank.

2- Inheritance: Some people leave some/ or all of their inheritance to Harvard University in order to support Harvard University in meeting its vision. The inheritance may include: funds, stocks, properties, or works of art.

3- Other sources: The projects carried out by Harvard University, such as: the university's park, the healthcare insurance of students, and the publishing and distribution institutions.

4- Social and economic units: Harvard University has social and economic units that are very competitive. Such units enable Harvard University to be ranked among the top 100 universities in the world.

\section{2) The Japanese Universities}

The Japanese universities established partnerships with researcher centers and the industrial sector. They established such partnerships in order to be capable of funding themselves and achieving technical and technological advancement. They established such partnerships in order to develop the industrial sector. The Japanese universities provide much attention to the establishment of such partnerships. That's because the Japanese 
government provides much attention to scientific research and technological developments. The latter attention can be manifested through the long-term economic development plan that was set by the Japanese government (Woolgar, 2007).

\section{3) The Saudi Model:}

The Saudi universities aim at strengthening their partnerships with the industrial institutions. To meet this goal, an initiative called (the research chairs) was launched. This initiative aims at providing the university with funds by someone or an institution in order to establish a suitable research environment (The website of King Saud University, 2011).

The reasons behind seeking to become productive universities:

Several developments have been experienced rapidly. The economic systems of most countries today are based on intellectual productivity, and the outcomes of scientific research. Therefore, universities must keep up with the latest developments to become very productive. According to Bufaltah (2015), many universities in developed countries are seeking to become productive universities. That's attributed to many reasons, such as:

1- Universities must seek serving community, conduct activities related to education and research. They must fund themselves

2- The knowledge-based economy has been receiving much attention

3- There is an increasing interest today in practicing total quality management in universities. In addition, university education today must aim at achieving development and enabling alumni to compete with the alumni of other countries. That can be done through developing the quality of university education and the outcomes of universities. That can be done through achieving consistency between the outcomes of universities and the requirements of development.

4- Developed and developing countries have been providing increasing attention to improving their competiveness. Due to such attention, several international agreements were made, such as: the General Agreement on Tariffs and Trade (GATT). Due to the increasing competiveness, universities must improve the qualifications of their alumni. They must enable their alumni to compete in the global labor market. They must improve their research-related outcomes.

\section{Previous Studies:}

El-Khelaiwy (2014) aimed to explore the reality of organizational culture in Saudi universities. She also aimed to explore the extent of turning into productive universities by Saudi universities. She aimed to explore the relationship between organizational culture and the extent of turning into productive universities. She aimed to identify the obstacles hindering Saudi universities from turning into productive universities. To meet the study's goals, a descriptive approach was adopted. A questionnaire was used and interviews were conducted. 375 questionnaire forms were distributed to faculty members who were selected from (King Saud University, King Abed Al-Aziz University, and King Fahd University of Petroleum and Minerals). 74 interviews were conducted. The interviewees include: managers of research centers at Saudi universities, deans, university presidents, and university representatives. It was found that respondents show moderate attitudes towards organizational culture in Saudi universities. It was found that the extent of turning into productive universities by Saudi universities is low. The latter researcher proposed a model for establishing an organizational culture that provides support for turning universities into productive universities.

Bufaltah (2015) conducted a case study in the University of Mentouri. He aimed to explore the effectiveness of turning the university into productive university that fund itself. He aimed to explore the role of the university in handling challenges. University aims at becoming productive for generating profits and funding itself. That shall positively affect the quality of its scientific research. It shall make the university financially independent and enjoying a high organizational agility level. It shall enable the university to establish partnerships with social and economic sectors. The productive university shall participate in achieving economic development. It shall enable the state to launch economic activities. In order for the university to become productive, there are requirements that must be met by the students, university management, society and business Institutions. For instance, there must be business Institutions that is ready to invest in the university's products and outcomes. The benchmarking method is considered the most effective method for turning the university into a productive university. That's because this method provides information about the performance of the leading universities in a specific area. That shall enable the university to benefit from such information and seek learning from the leading universities (Bufaltah, 2015).

Bani Maqdad (2016) aimed to explore the role of Al-Yarmouk University management in turning the university into a productive university. He aimed to identify the obstacles hindering Al-Yarmouk University from becoming a productive university. He aimed to provide suggested solutions for overcoming such obstacles. The study's population consists of (deans, vice deans, dean assistants and head of departments) who work at AlYarmouk University. It consists from 97 individuals. The sample was selected from the population. It consists from 72 individuals. To meet the goals, an instrument was developed. The first part of the instrument sheds a light 
on the role of the university management in turning the university into a productive university. This part covers three areas; education, scientific research, and community service. It consists from 49 items. The second part consists from open-ended questions. It aims at answering the second and third questions of the study. It was found that role of Al-Yarmouk university management in turning the university into a productive university is moderate. The educational area is ranked first and the community service area is ranked second. The scientific research area is ranked third. It was found that the obstacles hindering Al-Yarmouk University from becoming a productive university include: inadequate funding. The solutions provided for handling the latter obstacle include: (searching for new funding sources).

Mantikayan, and Abdulgani (2017) conducted a study titled: (Factors Affecting Faculty Research Productivity: Conclusions from a Critical Review of the Literature). They reviewed the relevant literature to identify the factors that affect the research productivity of faculty members at universities. A systematic literature review was conducted for addressing the study's problem. It was found that the personal factors that affect the research productivity of faculty members at universities include: self-efficacy, loyalty, motivation, commitment, orientations, advanced and basic researching skills, and desire to make achievements and contribute in the society's development. It was found that the personal factors also include: having a sense of responsibility, and independence, agility, desire to increase the research productivity, satisfaction of curiosity and pursing interests. It was found that the teaching-related factors that affect the research productivity of faculty members at universities include: (the load involving preparation for lectures, the extent of the support provided \& guidance provided for them, the resources available to them, moral and financial rewards, working hours, culture, promotion, social appreciation, standards, satisfactory performance, and colleagues). It was found that the leadership-related factors that affect the research productivity of faculty members at universities include: (the extent of considering the researcher as an important researcher, research orientations, and collaborating with departments that have similar research interests). It was found that the descriptive factors that affect the research productivity of faculty members at universities include: (the age, gender, IQ, and personality type of the faculty member).

Samue et al. (2017) aimed to analyze the productivity of each faculty member through conducting time series analysis. They targeted 200,000 research works of 2453 faculty members. These faculty members were selected from the computer science departments at US and Canadian universities. It was found that the social status and the department of the faculty member enable the latter researchers to predict the time interval between the first research and the last one. The latter researchers found that they aren't capable of predicting the research productivity of the faculty member throughout time. They recommend conducting studies about the way in which personal and environmental factors affect the scientific research productivity of faculty members.

\section{Recommendations}

The researchers recommend activating the role of Jordanian public universities as productive institutions. That can be done through meeting the industrial, educational, and business needs of society. That can be done through:

1- Ensuring that all the society's members have equal opportunities to receive education

2- Adopting a comprehensive strategy for achieving consistency between the outcomes of the universities' scientific research and the society's needs

3- Establishing networks for advertising research

4- Establishing effective partnerships between the private sector and universities. That can be done through having consultancy service offices in business companies. Such offices shall be affiliated with a university.

5- Establishing training centers in cooperation with universities. Such centers must aim at training alumni and providing them with the necessary skills and expertise before they enter the labor market

6- Building hospitals that are affiliated with Mu'tah University and Al-Yarmouk University in order to turn these universities into productive universities

\section{References}

\section{References written in Arabic language:}

- Ibrahim, Majdi Aziz (2014). The creative aspects of university education: The spirit of challenge to achieve advancement. Cairo: Alam Al-Kutub publication and distribution house.

- Battah, Ahmad (2017). Contemporary issues related to higher education. Amman: Wa'el publication and distribution house

- $\quad$ Bani Maqdad, Na'eemeh Ali (2016). The role of university management in turning Al-Yarmouk university into productive university: Obstacles and solutions: Unpublished $\mathrm{PhD}$ dissertation. Irbid: Yarmouk University.

- Bufaltah, Mohammad Saif Al-Deen (2015). The attitudes towards turning university into productive university to fund itself: A case study in University of Mentouri. The Human Sciences Journal. 43(B) Mentouri. Algeria. 377-392

- Public Jordanian Universities (2016). The budget of Public Jordanian Universities for the year (2017). Jordan. 
Amman

- $\quad$ King Saud University. (2011). Research chairs. The website: http://c.ksu.edu.sa.

- Al-Khateeb, Ahmad (2009): Higher education: Problematic issues and challenges. Irbid. Alam Al-Kutub publication and distribution house.

- El-Khelaiwy, Lina bent Sulaiman ben Ali (2014). The productive university and its relationship with organizational culture in Saudi Universities: A proposed model. Unpublished PhD dissertation. KSA. Riyad. King Saud University.

- $\quad$ Al- Rahahleh, E. (2011). Community responsibility. Jordan. The Arab Community bookshop for publication and distribution house.

- $\quad$ Shahin, M. (2012). Community responsibility in Arab Universities: Al-Quds Open University as a model: An analytical descriptive approach. Palestine. The Publications of Al-Quds Open University.

- Shaqwarah, Sana' Ali (2013). The role of transformation leadership in boosting the extent of handling community responsibility by private universities in Jordan. Unpublished PhD dissertation. Jinan University. Tripoli, Lebanon.

- Al-Tarawneh, Ekhlaif (2015). Vision and ideas related to higher education institutions. Amman: Al-Majd publication and distribution house.

- Azb, Mohamad Ali (2011). University education and development-related issues. Cairo. The Egyptian Anglo Bookshop

- E'laiwy, Hussain Zyoon (2017) Analysis of the impacts of investing in the human capital on the productive university (South Korea, KSA, and Iraq): Case study. Kuwait Journal for administrative and economic sciences. 25. 1-25

- E'naya, Gazi, (2014). Scientific research: The methodology adopted for conducting research and university theses. Amman. Al-Manaheg publication and distribution house.

- Kamal, S. (2011). The internal conditions of the success of university in handling community responsibility: The proceedings of the conferences titled (community responsibility of Palestinian universities). : Al-Quds Open University. Palestine. Nables. 33-35

- The Economic and Social Council (2018). The financial status of public universities in Jordan: Jordan. Amman

- Namour, Nawal (2012). The efficiency of the faculty members and its impact on the higher education quality: A case study in the faculty of economic and management sciences. Unpublished MA thesis. Algeria: University of Mentouri

- Ya'qoub, Mohammad Al-Baqer Haj (2011). Sciences and its impact on knowledge management from an Islamic perspective. Islam in Asia Journal. 4. Special Issue. 1-26

\section{References written in English language}

- Ahmadi, F.(2012). Social Responsibility in universities: Case Study, Iranian University. Interdisciplinary Journal of Contemporary Research in Business, 3(1), 298-306.

- $\quad$ Badat, S.(2009). The role of higher education in society. Valuing higher education .

- $\quad$ Boardman, P.(2009). Craig: Government Centrality to University Industry Interactions: University Research Centers, Research Policy, 38(10).pp.

- Delahaye, B \& Choy, S. (2011) Partnerships between universities and workplaces: Some challenges for workintegrated learning. Studies in Continuing Education, 33(2), 157-172.

- Dryden, G (2002). Transforming Education: Nine Steps to Transform Education.http://www.newhorizons.org.

- Mantikayan., M., Jonathan \&Abdulgani, A., Montadzah (2017) Factors Affecting Faculty Research Productivity: Conclusions from a Critical Review of the Literature. Conference: Conference: 7 th International Conference on Multidisciplinary Research, At Cagayan de Oro City, Philippines.

- $\quad$ Minea, A.(2013). The Social Responsibility of university. The Role of the Front office Personnel, Journal of Social Economy, 111(2). p.57-73.

- $\quad$ Moore, T.(2010). Institutionalizing Faculty engagement through research, teaching, and service at research universities. Michigan Journal of Community Service learning, 17(1), 44-58.

- Samue., F. Way, Allison C. Morgan, Aaron, Clauset, and Daniel B. Larremore (2017) The misleading narrative of the canonical faculty productivity trajectory. arXiv:1612.08228v2 [cs.DL] 17 Oct 2017.

- Woolgar, Lee.(2007). New International Policies For University Industry Links in Japan, Research Policy, $36(8)$. 